\title{
Higher Education Efficiency and Quality
}

\author{
Marcin Dwórznik*, Krzysztof Opolski* ${ }^{* *}$
}

The efficiency and the quality of higher education institution was assessed with the use of process approach. The efficiency of the higher education institution was determined on the basis of a combination of typical financial measures, taking into account costs incurred in the process of didactics and research, and expenditures (measured by current liquidity, stock turnover, receivables and liabilities ratios) necessary for schools to maintain financial liquidity. As measures of quality, related to statutory tasks of the university, the factors determining graduates' situation on the labour market as well as patents obtained as a result of research conducted by university were adopted. Applying measures of quality enabled the researcher to obtain a more comprehensive dimension of the universities' efficiency, while proving the fact that financial measures alone may distort the actual picture of efficiency or even lead to erroneous conclusions.

It can be hypothesized that in the case of a higher education institution that pursues its statutory goals of providing knowledge to the public by conducting didactics and research, the concept of efficiency should combine financial and qualitative dimensions.

The results obtained in the study using the DEA method allow the researcher to determine the situation of the university for the period covered by the study.

Keywords: higher education, quality, efficiency, higher education institution, organizational effectiveness, didactics, research.

Submitted: 29.09.2021 | Accepted: 26.11.2021

\section{Efektywność i jakość kształcenia wyższego}

Efektywność i jakość uczelni oceniano przez prywmat realizowanych przez nie procesów. Efektywność uczelni została określona na podstawie kombinacji typowych miar finansowych, uwzględniajacych koszty poniesione w procesie dydaktyki i badań oraz naktadów (mierzonych plynnościa bieżaca, obrotami zapasami, należnościami $i$ wskaźnikami zobowiazań) niezbędnych szkołom do utrzymania plynności finansowej. Jako mierniki jakości, zwiazane z zadaniami statutowymi uczelni przyjęto czynniki determinujące sytuację absolwentów na rynku pracy oraz patenty uzyskane w wyniku badań prowadzonych przez uczelnie. Zastosowanie miar jakościowych pozwolito badaczowi uzyskać bardziej kompleksowy wymiar efektywności uczelni, udowadniajac jednocześnie, że same środki finansowe moga znieksztatcać rzeczywisty obraz efektywności, a nawet prowadzić do btędnych wniosków.

\footnotetext{
Marcin Dwórznik - dr, Department of Management and Information Technology, Faculty of Economic Sciences, Uniwersity of Warszaw, Poland, https://orcid.org/0000-0001-5861-2729.

** Krzysztof Opolski - prof. dr hab., Department of Management and Information Technology, Faculty of Economic Sciences, Uniwersity of Warszaw, Poland, https://orcid.org/0000-0001-8191-5031.

Correspondence address: Department of Management and Information Technology, Faculty of Economic Sciences, Uniwersity of Warszaw, 44/50 Długa, 00-241 Warsaw, Poland; e-mail: mdworznik@ wne.uw.edu.pl.
} 
Można postawić hipoteze, że w przypadku uczelni, która realizuje swoje statutowe cele przekazywania wiedzy spoteczeństwu poprzez prowadzenie dydaktyki i badań, pojęcie efektywności powinno taczyć wymiar finansowy i jakościowy.

Wyniki uzyskane w badaniu metoda DEA pozwalaja badaczowi określić sytuację uczelni w okresie objętym badaniem.

Słowa kluczowe: szkolnictwo wyższe, jakość, efektywność, szkoła wyższa, skuteczność organizacyjna, dydaktyka, badania.

JEL: I230, I220, I230, M400, M100, R32

\section{Introduction}

To assess the functioning of an organization, an important objective is to measure its efficiency. In order to do so, it is necessary to conduct multidimensional assessment, taking into account, inter alia, financial (such as ability to service current liabilities, the level of financial result), organizational and social aspects. Higher education system plays a significant role in the modern economy (especially in the knowledge economy), therefore an important research challenge is to create the methodology of measuring the efficiency of higher education institution's functioning. It is particularly essential in the case of public higher education institution, as they must manage their assets in order to meet the specified goals without achieving a negative financial result ${ }^{1}$, which may at times indicate their inefficient management $^{2}$. At the same time, public higher education institution (contrary to private ones) are obliged to carry out legitimate, effective, and cost-efficient activities with timely implementation of their tasks and goals ${ }^{3}$.

Ulrich Teichler draws attention to the issue of new challenges for higher education in his article "Universities Between the Expectations to Generate Professionally Competences and Academic Freedom Experiences from Europe" published in 2013. He states that at the beginning of the 21st century traditional higher education institutions seem to be at risk in Europe, due to the fact that many actors and experts are in favor of a close link between higher education market and the labor market.

In light of these fears, the assessment of the functioning of higher education institution, apart from measurement of efficiency with respect to an economic dimension, should take into account other aspects resulting from the role served towards society (equated with quality). Therefore, public higher education institution should pay particular attention to the implementation of social goals resulting from their vision and mission ${ }^{4}$. It is especially important not only to measure efficiency but also organizational effectiveness of the higher education institution as a whole. Due to different nature of two main higher education institution processes (teaching and research) it is particularly noteworthy to create research methodology measuring efficiency and quality of each of the conducted processes separately as well as linkages between them that in the end, should allow for complex assessment of the functioning of the university.

The problem raised at work is also important from the point of view of the contemporary conditions in which higher education institutions operate. The prevailing conditions often require higher education institutions to use other tools in the education process, such as social media, where monitoring of their use is also important (Maślanka \& Brzezicki, 2020).

\section{Research Assumptions}

In the article, a proposal of the research methodology for measuring efficiency, quality and organizational effectiveness of higher education institutions will be presented. It can be hypothesized that in the case of a higher education institution that pursues its statutory goal of providing knowledge to the public by conducting didactics and research, the concept of efficiency should combine financial and qualitative dimensions. The research hypothesis states a presence of inverse proportion between efficiency and quality (that is the higher efficiency, the lower quality).

Striving to improve efficiency may have a negative impact on the level of quality 
achieved. This is due to the fact that quality improvement is often associated with the necessity to incur additional costs (effectiveness, the goal must be achieved regardless of costs). On the other hand, in the case of efficiency, attention is paid to maintaining the relationship between costs and revenues, in favor of revenues. In view of the above, when analyzing the definitions of two concepts (efficiency and quality), one can notice a certain contradiction between them. In the literature, you can find many studies analyzing the efficiency of higher education institutions. They refer to the aspect of the efficiency of the functioning of higher education institutions, but there is no mention of the quality aspect. A study similar to the one presented in this article is the study "Effectiveness and efficiency of academic education on the example of the Warsaw University of Life Sciences" (Pietrzak \& Gołaś, 2018). The number of graduates of full-time second-cycle studies (in persons) was assumed as the results of the activity of the university in question. In turn, the effectiveness of faculties' education was measured (data from BLA): remuneration of graduates in relation to the place of residence (number), time of seeking employment by graduates (in months) and the risk of unemployment in relation to the place of residence (number). Based on the conducted research, it was found that no unit was characterized by the highest/lowest effectiveness and efficiency at the same time.

The efficiency and the quality of higher education institutions was assessed with the use of process approach. In addition, at the higher education institutions as at any other organization, a number of auxiliary activities processes is conducted such as accounting, IT, maintenance of real estate - which altogether can be named as support activities. In case of support activities, they provide services to the main processes (didactics and research). Efficiency of conducting these activities has a measurable effect on leading main processes. For this reason, their assessment will be conducted from the point of view of organizational effectiveness.

Before embarking on assessing efficiency and quality it is necessary to define them. The efficiency of the higher education institution was determined on the basis of a combination of typical financial meas- ures, taking into account costs incurred in didactics and research, and expenditures (measured by current liquidity, stock turnover, receivables and payables turnover ratios) necessary for teaching institutions to maintain financial liquidity.

Efficiency is best defined as the ratio of the resources used to the products obtained (in the case of higher education institution, education services are more appropriate). Reviewing scientific literature pertaining to definition and types of efficiency, one can often find a citation to scheme decomposing cost effectiveness proposed by Camanho and Dyson (2005).

They proposed that cost efficiency is composed of output efficiency and cost efficiency. Moreover, cost efficiency is determined by input allocation efficiency and technical efficiency. The latter efficiency is a result (multiple) of pure technical efficiency and scale efficiency. The second concept, which should be defined, is quality. Definition of quality according to ISO 9000 is "an extent to which a set of inherent properties meets set criteria"5. In light of this, quality of a higher education institution depends on characteristics which the higher education institution possesses. Creation of characteristics is significantly dependent on the organization itself. An important impact on determining characteristics of higher education institutions have processes conducted by them. Meeting the needs should be understood as meeting the needs of stakeholders. As measures of quality related to statutory tasks of higher education institution - the factors that determine graduates' situation on the labor market as well as patents obtained as a result of research conducted by higher education institution were adopted. Applying measures of quality enabled us to obtain a more comprehensive dimension of the higher education institution' efficiency, while proving the fact that financial measures alone may distort the actual picture of efficiency or even lead to erroneous conclusions.

There are two main dimensions of quality of the higher education institution. The first can be defined as internal quality which means perceiving a quality of the higher education institution through a set of factors directly dependent on the organization such as the quality of infrastructure or the quality of teaching. The second dimension maybe identified with 
external quality on which the higher education institution has indirect impact such as situation of graduates on the labor market. The higher education institution has direct impact on competences transferred to graduates, nevertheless acquired by graduates competences are signals based on which employers access employee after his/her employment. On decisions taken by employers, higher education institutions however have no direct influence.

To measure efficiency from the viewpoint of inputs, financial measures will be used, which are mentioned in scientific literature. The review of literature on the subject of financing of higher education institutions reveals that the most important factor in cost structure of higher education institutions are salaries and wages (which was confirmed, among others, by Falcon (1973) and Franco (1991)). Franco (1991) conducted cost analysis of the higher education institutions dividing them into public and private institutions. Performed analyses showed that costs per student at public higher education institutions are over two times higher than in the case of private institutions. Salaries and wages are an important cost at both private and public higher education institutions. In general, in the structure of costs, over $50 \%$ constitute operating costs. Both at public and private higher education institutions, investments are on a very low level in relation to operating costs (in case of public higher education institutions they constituted less than 5\% and at private universities approximately $20 \%$ ). In addition, Capaldi and Abbey (2011) pointed out to a variation in educational costs based on the type of scientific discipline taught, which means that in a research sample should be included higher education institutions conducting didactics in various scientific areas.

Organizational effectiveness (in this work) is defined as effectiveness of internal processes of an organization and resources can ensure resources necessary for their implementation. It is understood as achieving specified by an organization a set of "internal" goals (for example, preferred level of financial ratios), in this work used to measure effectiveness realized by higher education institution processes supporting the main processes (didactics and research). Organizational effectiveness will be assessed through the main goal set for the public higher education institution 6 in the Public Finance Act $^{7}$ - efficient management of owned assets ${ }^{8}$.

The logic diagram of the methodology for conducting the study of the efficiency and quality of the higher education institution was presented in the figure below.

Figure 1. The logic diagram of the methodology for conducting the study of the efficiency and quality of the higher education institution

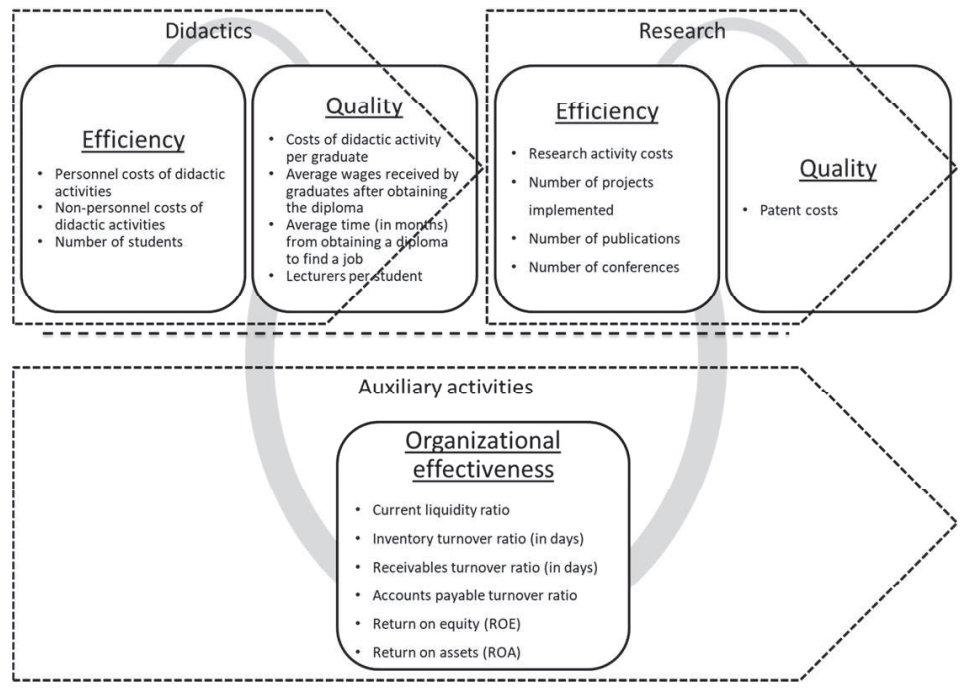

Source: Own elaboration.

Wydział Zarządzania UW https://doi.org/10.7172/1733-9758.2021.35.4 


\section{Research Method}

The non-parametric measurement method - DEA was used to measure the efficiency and quality of the higher education institution. For the first time the DEA model was proposed by Charnes, Cooper and Rhodes in 1978, named CCR from the first letters of each author's surname. It is a proposal of linear solution to non-linear problem. In CCR model, there is a concept of technical efficiency used under assumption of fixed effects of scale. The model assumes that a decision making unit (DMU) is efficient if the quotient of weighted input sums and weighted output sums is equal to 1 and simultaneously when all weights are bigger than 0 . The above assumption can be written using the formula (Cooper, Seiford, \& Tone, 2000, as cited in Modzelewski, 2009):

$$
1=\frac{U 1 Y 1 o+U 2 Y 2 o+(\ldots)+U n Y n o}{V 1 X o+V 2 X 2 o+(\ldots)+V n X n o},
$$

where:

$U$ - output weight, under assumption of $U 1$, (...) $U n>0$

$Y$ - output

$V$ - input weight, under assumption of V1, (...) $V n>0$

$X$ - input

A limitation of CCR model is application of fixed effects of scale. When calculating technical efficiency, variable effects should be considered (Modzelewski, 2009). Taking into consideration variable effects of scale is particularly important in research on higher education institutions, where often sizable differences exist in estimated amounts of inputs and outputs. To measure the level of variable effects the model proposed by Banker, Chames and Cooper in 1984 known as BCC model can be used. This model takes into consideration variable effects of scale.

Thanks to application of DEA method, it is possible to omit the problem of knowing the production function. This is especially important in research on higher education institutions, where there are many autonomous units realizing the same main processes (which are didactics and research).

Reassuming, the DEA method does not create necessity of stating weights. For the researched unit efficiency is defined based on solving linear problem in which rela- tion between inputs and outputs is maximized without any limitations. Such an approach allows the researchers to identify strong points of the unit. Moreover, in this method it is possible to identify resources which are not necessarily used by the unit to achieve the outputs but which nevertheless are applied by the unit, known as empty costs (Thanassoulis, 2003).

The research which concerned higher education using DEA method was conducted, among others, in England (Thanassoulis, Kortelainen, Johnes, \& Johnes, 2011; Bradley, Johnes, \& Little, 2006), Spain (Taylor \& Tyler 2012), Austria (Leitner, Prikoszovits, Schaffhauser-Linzatti, Stowasser, \& Wagner, 2007), South America (Taylor \& Harris, 2004), Canada (McMillan \& Datta, 1998), Chile (Ramírez-Correa, Peña-Vinces, \& Alfaro-Pérez, 2012), Japan (Kaneko, 1997), and Australia (Taylor, 2011).

In literature, you can find numerous publications dealing with the issues of efficiency of Polish higher education institutions. As an example, the following publications can be cited: Dwórznik (2018); Brzezicki and Pietrzak (2018); Brzezicki (2017); Nazarko, Chodakowska and Jarocka (2012); Czapiewski and Janc (2013); Pietrzak and Baran (2018).

Nevertheless, the quality of higher education institutions is often assessed in the context of a given higher education institution's position in international rankings. In the above context, the position of Polish higher education institutions is not very positive. Polish higher education institutions are classified in distant places, identified as places in the next hundreds (Janc, 2021).

As basis for the conducted analysis financial data presented by the higher education institutions in financial statements were used. Higher education institutions publish financial statements in accordance with Polish Accounting Standards (Polish Accounting Act) in "Monitor Sądowy i Gospodarczy". In this research, also publicly available data published in statements by rectors of particular higher education institutions, information available on POLon portal (information about Polish education) and public statistics made available by Statistics Poland were used.

When making a decision which higher education institutions should be placed in the research sample, key criteria which have 
an impact on efficiency and functioning of universities were considered. Among the criteria of choosing a research sample were:

- The size of higher education institutions (mainly in light of the number of current students);

- Diversity of higher education institutions based on available study paths (universities, academies of economics, technical universities);

- The size of the city where the campus is located (big cities).

Taking into consideration three of the above criteria, 22 public higher education institutions fitting these criteria were cho- sen. This group included 10 universities, 6 technical universities and 5 academies of economics as well as 1 agricultural academy. The chosen sample is characterized by similar level of outputs in one of the two main processes that is didactics, which output is the number of students being educated. The factor affecting differences in operational efficiency is the level of costs related to conducted activities. The list of higher education institutions (ranked from the point of view of the number of current students) included in sample together with the number of current students is presented below.

Table 1. Research sample of higher education institutions for which efficiency, quality and organizational effectiveness were estimated

\begin{tabular}{|c|c|c|c|c|c|}
\hline No. & Name of institution & $\begin{array}{c}\text { Abbreviated } \\
\text { institution name }\end{array}$ & $\begin{array}{c}\text { Location } \\
\text { of institution }\end{array}$ & $\begin{array}{c}\text { Number } \\
\text { of students } \\
\text { in } 2015\end{array}$ & Type of institution \\
\hline 1. & University of Warsaw & UW & Warsaw & 44848.00 & University \\
\hline 2. & Jagiellonian University in Cracow & UJ & Cracow & 41818.00 & University \\
\hline 3. & Adam Mickiewicz University in Poznań & UAM & Poznań & 39982.00 & University \\
\hline 4. & University of Łódź & UŁ & Łódź & 33909.00 & University \\
\hline 5. & University of Wrocław & Uwroc & Wroclaw & 26054.00 & University \\
\hline 6. & Warsaw University of Life Sciences & SGGW & Warsaw & 22548.00 & Agricultural academy \\
\hline 7. & Nicolaus Copernicus University in Toruń & UMK & Torun & 25485.00 & University \\
\hline 8. & University of Gdańsk & UG & Gdansk & 27233.00 & University \\
\hline 9. & $\begin{array}{l}\text { Maria Curie-Skłodowska University } \\
\text { in Lublin }\end{array}$ & UMCS & Lublin & 21874.00 & University \\
\hline 10. & University of Silesia in Katowice & UŚ & Katowice & 24484.00 & University \\
\hline 11. & $\begin{array}{l}\text { University of Warmia and Mazury } \\
\text { in Olsztyn }\end{array}$ & UWM & Olsztyn & 23205.00 & University \\
\hline 12. & $\begin{array}{l}\text { University of Science and Technology } \\
\text { in Cracow }\end{array}$ & $\mathrm{AGH}$ & Cracow & 30262.00 & Technical university \\
\hline 13. & Gdańsk University of Technology & PG & Gdansk & 23017.00 & Technical university \\
\hline 14. & Poznań University of Technology & PP & Poznań & 20052.00 & Technical university \\
\hline 15. & $\begin{array}{l}\begin{array}{l}\text { Silesian University of Technology } \\
\text { in Gliwice }\end{array} \\
\end{array}$ & PŚ & Gliwice & 22923.00 & Technical university \\
\hline 16. & Warsaw University of Technology & PW & Warsaw & 33360.00 & Technical university \\
\hline 17. & Wrocław University of Technology & Pwroc & Wrocław & 33530.00 & Technical university \\
\hline 18. & Warsaw School of Economics Cracow & SGH & Warsaw & 12363.00 & Academy of economics \\
\hline 19. & Cracow University of Economics & UEK & Cracow & 20869.00 & Academy of economics \\
\hline 20. & The Poznań University of Economics & UEP & Poznań & 10422.00 & Academy of economics \\
\hline 21. & Wrocław University of Economics & UEW & Wroclaw & 12271.00 & Academy of economics \\
\hline 22. & University of Economics in Katowice & WEKat & Katowice & 10929.00 & Academy of economics \\
\hline
\end{tabular}

Source: Own elaboration based on "Szkoły wyższe i ich finanse 2015", GUS (Statistics Poland), Warszawa, 2016. 
Calculating efficiency (both with fixed and variable effects of scale) was conducted using EMS $^{9}$ program. Diagrams were created using SPSS package ${ }^{10}$.

\section{Research Results - Didactic Activity}

Conducted research of cost efficiency $(\mathrm{OE})^{11}$ for the researched sample of higher education institutions pertaining to activities of the didactic process showed the highest cost efficiency in the group at the level of 1 - this was characteristic of one academy of economics - Cracow University of Economics. This means that this school with respect to others in the research sample has the most beneficial relation of inputs (incurred costs for didactic activities with specified personnel costs 12 and non-personnel costs ${ }^{13}$ ) to outputs (the number of current students) ${ }^{14}$. Similar conclusions can be reached if we analyze the researched higher education institutions from the point of view of pure technical efficiency (CCR efficiency). Limiting the output analysis only to efficiency with variable effects of scale (BCC efficiency) it can be noted that the highest efficiency in the sample at the level of 1 is characteristic of two academies of economics: Cracow University of Economics and University of Economics in Katowice and four universities: University of Warsaw, Jagiellonian University in Cracow, Adam Mickiewicz University in Poznań and University of Lodz. Efficiency ratios at the lowest level in the researched sample are characteristic of technical universities. Results of the analysis are consistent with the type of institution in the study sample. Didactic process at technical universities requires higher inputs for teaching (among others, due to need for having laboratories). This may, in principle, make them less efficient than the other types of institutions. Similar results are obtained by analyzing pure technical efficiency (the highest efficiency ratios at the level of 1 in the study sample were obtained in case of four universities: University of Warsaw, Jagiellonian University in Cracow, Adam Mickiewicz University in Poznań and University of Lodz educating the highest number of students and two academies of economics: Cracow University of Economics and University of Economics in Katowice). Detailed results of the conducted analysis are shown in table "Values of partial efficiency measures in the didactic process".

The conducted analysis of correlations among variables used to assess efficiency and quality of conducted didactic process showed that there are significant statistical correlations between them. Some of the existing correlations can be described as "natural", where with an increase in one variable another one increases, for example, an increase in the number of current students leads to higher education institution incurring higher costs, both personnel and non-personnel, of conducted didactic process. This can also lead to a conclusion that in case of universities economies of scale do not exist, which means that with an increase of scale, costs of operation decline. An interesting observation is a positive correlation 15 among non-personnel costs of didactic activities and the length of time needed to find a job ${ }^{16}$ by a graduate since graduation. A positive correlation ${ }^{17}$ was also observed in case of personnel costs of didactic activities in relation to time needed to find a job ${ }^{18}$ by a graduate since graduation. This can lead to a conclusion that the higher the costs related to didactic activities, the longer it takes for a graduate to find a job. If the above fact is linked to positive correlation ${ }^{19}$ of the number of current students and the length of time needed to find a job by a graduate since graduation, it could be assumed that universities which educate a higher number of students ${ }^{20}$ have among their graduates people for whom it is potentially more difficult to find a job (in other words, they educate people for whose skills there is relatively small demand on the labor market ${ }^{21}$ ).

\section{Research Results - Research Activity}

Conducted study of the cost efficiency $(\mathrm{OE})^{22}$ for the sample of higher education institutions conducting research activities showed the highest cost efficiency in the studied sample at the level of 1 at one academy of economics, an identical result as it was in the case of didactic process and additionally one academy of economics: University of Economics in Katowice. Performing the analysis from the point of view of fixed effects of scale, the highest efficiency at the level of 1 (CCR effi- 
Table 2. Values of partial efficiency measures in the didactic process

\begin{tabular}{|c|c|c|c|c|c|c|}
\hline $\begin{array}{c}\text { Higher education } \\
\text { institution }\end{array}$ & $\begin{array}{l}\text { Total cost } \\
\text { efficiency }\end{array}$ & $\begin{array}{c}\text { CCR efficiency } \\
\text { (Constant Scale } \\
\text { Effects) }\end{array}$ & $\begin{array}{c}\text { Efficiency } \\
\text { of resource } \\
\text { allocation }\end{array}$ & $\begin{array}{c}\text { BBC efficiency } \\
\text { (Variable Scale } \\
\text { Effects) }\end{array}$ & $\begin{array}{c}\text { Scale } \\
\text { efficiency }\end{array}$ & $\begin{array}{l}\text { Pure technical } \\
\text { efficiency }\end{array}$ \\
\hline UW & 0.318 & 0.332 & 0.96 & 1 & 0.3318 & 1 \\
\hline UJ & 0.404 & 0.407 & 0.99 & 1 & 0.4070 & 1 \\
\hline UAM & 0.492 & 0.488 & 1.01 & 1 & 0.4882 & 1 \\
\hline UE & 0.635 & 0.640 & 0.99 & 1 & 0.6404 & 1 \\
\hline Uwroc & 0.481 & 0.478 & 1.01 & 0.6182 & 0.7734 & 0.6182 \\
\hline SGGW & 0.502 & 0.499 & 1.01 & 0.5538 & 0.9005 & 0.5538 \\
\hline UMK & 0.475 & 0.475 & 1.00 & 0.6032 & 0.7873 & 0.6032 \\
\hline UG & 0.610 & 0.632 & 0.97 & 0.8457 & 0.7471 & 0.8457 \\
\hline UMCS & 0.542 & 0.540 & 1.00 & 0.5763 & 0.9367 & 0.5763 \\
\hline UŚ & 0.467 & 0.464 & 1.01 & 0.5662 & 0.8199 & 0.5662 \\
\hline UWM & 0.461 & 0.457 & 1.01 & 0.525 & 0.8705 & 0.525 \\
\hline AGH & 0.392 & 0.389 & 1.01 & 0.567 & 0.6857 & 0.567 \\
\hline PG & 0.473 & 0.474 & 1.00 & 0.5404 & 0.8775 & 0.5404 \\
\hline PP & 0.479 & 0.475 & 1.01 & 0.4806 & 0.9883 & 0.4806 \\
\hline PŚ & 0.374 & 0.373 & 1.01 & 0.4221 & 0.8825 & 0.4221 \\
\hline PW & 0.369 & 0.367 & 1.01 & 0.5701 & 0.6430 & 0.5701 \\
\hline Pwroc & 0.420 & 0.459 & 0.92 & 0.7223 & 0.6349 & 0.7223 \\
\hline SGH & 0.546 & 0.562 & 0.97 & 0.6584 & 0.8534 & 0.6584 \\
\hline UEK & 1 & 1 & 1.00 & 1 & 1 & 1 \\
\hline UEP & 0.4754 & 0.6945 & 0.68 & 0.8936 & 0.7772 & 0.8936 \\
\hline UEW & 0.6878 & 0.7210 & 0.95 & 0.8471 & 0.8511 & 0.8471 \\
\hline WEKat & 0.7951 & 0.8150 & 0.98 & 1 & 0.8150 & 1 \\
\hline
\end{tabular}

Source: Own elaboration.

ciency) is exemplified by four academies of economics: University of Economics in Katowice, Wrocław University of Economics, The Poznań University of Economics and Warsaw School of Economics and one technical university: Wrocław University of Technology. These results in case of academies of economics can be linked to their field of study. In principle, this group of higher education institutions focuses mostly on conducting didactic process and limited research scope should improve cost control in research. Restricting the analysis to only variable effects of scale gives us four additional universities: University of Warsaw, Jagiellonian University in Cracow,
Adam Mickiewicz University in Poznań and University of Warmia and Mazury in Olsztyn that show the highest efficiency at the level of 1 . The last conclusion which can be confirmed is that the size of higher education institutions allows for effects of scale in research activities (among others, easier access to infrastructure, bigger bargaining power when making purchases). The analysis of pure technical efficiency leads to the same results as in the case of the sample studied from the point of view of efficiency with variable effects of scale (BCC efficiency). It is worth to mention that conducted analysis of correlations does not show statistically significant cor- 
relations between efficiency of research and research costs. Detailed results of conducted study are shown in the table "Values of partial efficiency measures in the didactic process".

Table 3. Values of partial efficiency measures in the didactic process

\begin{tabular}{|c|c|c|c|c|c|c|}
\hline $\begin{array}{c}\text { Higher education } \\
\text { institution }\end{array}$ & $\begin{array}{l}\text { Total cost } \\
\text { efficiency }\end{array}$ & $\begin{array}{c}\text { CCR efficiency } \\
\text { (Constant Scale } \\
\text { Effects) }\end{array}$ & $\begin{array}{l}\text { Efficiency } \\
\text { of resource } \\
\text { allocation }\end{array}$ & $\begin{array}{c}\text { BBC efficiency } \\
\text { (Variable Scale } \\
\text { Effects) }\end{array}$ & $\begin{array}{c}\text { Scale } \\
\text { efficiency }\end{array}$ & $\begin{array}{c}\text { Pure technical } \\
\text { efficiency }\end{array}$ \\
\hline UW & 0.119434 & 0.2684 & 0.444984 & 1 & 0.2684 & 1 \\
\hline UJ & 0.122697 & 0.1483 & 0.827355 & 1 & 0.1483 & 1 \\
\hline UAM & 0.095733 & 0.2037 & 0.469972 & 0.5004 & 0.407074 & 0.5004 \\
\hline UŁ & 0.189249 & 0.2306 & 0.820683 & 0.8437 & 0.27332 & 0.8437 \\
\hline Uwroc & 0.192654 & 0.2387 & 0.807095 & 0.9363 & 0.25494 & 0.9363 \\
\hline SGGW & 0.203639 & 0.3279 & 0.621041 & 0.4299 & 0.762736 & 0.4299 \\
\hline UMK & 0.382674 & 0.6271 & 0.610228 & 1 & 0.6271 & 1 \\
\hline UG & 0.327958 & 0.438 & 0.748762 & 0.811 & 0.540074 & 0.811 \\
\hline UMCS & 0.330736 & 0.3554 & 0.930602 & 0.7454 & 0.476791 & 0.7454 \\
\hline UŚ & 0.2454 & 0.3247 & 0.755774 & 0.7124 & 0.455783 & 0.7124 \\
\hline UWM & 0.306014 & 0.3507 & 0.872581 & 1 & 0.3507 & 1 \\
\hline $\mathrm{AGH}$ & 0.040543 & 0.2048 & 0.197962 & 0.3156 & 0.648923 & 0.3156 \\
\hline PG & 0.053485 & 0.1546 & 0.34596 & 0.1599 & 0.966854 & 0.1599 \\
\hline PP & 0.048951 & 0.3006 & 0.162846 & 0.3088 & 0.973446 & 0.3088 \\
\hline PŚ & 0.069985 & 0.2753 & 0.254215 & 0.4988 & 0.551925 & 0.4988 \\
\hline PW & 0.073138 & 0.2288 & 0.319661 & 0.3366 & 0.679739 & 0.3366 \\
\hline Pwroc & 0.06885 & 1 & 0.06885 & 1 & 1 & 1 \\
\hline SGH & 0.885811 & 1 & 0.885811 & 1 & 1 & 1 \\
\hline UEK & 0.602211 & 0.8164 & 0.737642 & 0.8649 & 0.943924 & 0.8649 \\
\hline UEP & 0.474957 & 1 & 0.474957 & 1 & 1 & 1 \\
\hline UEW & 0.979499 & 1 & 0.979499 & 1 & 1 & 1 \\
\hline WEKat & 1 & 1 & 1 & 1 & 1 & 1 \\
\hline
\end{tabular}

Source: Own elaboration.

The conducted correlation analysis of variables used to assess efficiency and quality of research process showed a positive correlation among the number of publications $^{23}$ and the number of organized conferences $^{24}$, as well as the costs incurred due to obtaining a patent ${ }^{25}$. This can lead to a conclusion that, requirements of organizations providing financing for research as a result of which a patent is obtained, pertaining to so-called promotion of research results in form of publications and organized conferences causes an increase in costs of obtaining a patent. It is worth to mention a fact that no correlation was found between the number of realized research projects and the costs of obtaining a patent. A statistically significant, positive correction was found between the number of realized projects and the number of publications ${ }^{26}$ 
and organized scientific conferences 27 . This is consistent with practice according to which as part of every research project, a scientific publication should be drawn up and as part of most research projects conferences summing up the research results should be organized.

\section{Research Results - Organizational Efficiency}

Organizational efficiency was measured from a point of view of a higher education institution. On the one hand, ratios were analyzed which could be used to measure organizational liquidity - current liquidity ratio (calculated as a relation between the value of current assets and current liabilities), inventory turnover, accounts receivable turnover, accounts payable turnover and, on the other hand, profitability ratios (ROE and ROA). As part of liquidity ratios, current liquidity ratio was selected along with KON ratio, one similar in its construction to working capital ratio calculated as a difference between inventory turnover ratio and accounts receivable ratio and accounts payable ratio.

Comparing liquidity ratio with return on equity ratio leads to a conclusion that in the studied group of higher education institutions, there are no institutions which are simultaneously characterized by a high level of liquidity and ROE profitability. High level of ROE was found in case of University of Łódź. Simultaneously one higher education institution showed relatively low level of liquidity, close to 1 (which means that accounts receivable are on a similar level as accounts payable). This can stem from implementing cost accounting at the higher education institution (rested upon Activity Based Costing, which allows for, on the one hand, due to cost control, obtaining a higher value of ROE, and on the other hand, for more aggressive management of working capi- tal). At the same time, it should be noted that the other higher education institutions are characterized by a relatively low level of ROE ratio, still they can be divided into two groups. The first group includes institutions with a relatively high level of liquidity (a value higher by $50 \%$ of the average value for the whole group). In this group there two academies of economics: Cracow University of Economics and Wrocław University of Economics; three universities: University of Wrocław, Jagiellonian University in Cracow, University of Warsaw and five technical universities: AGH University of Science and Technology in Cracow, Gdańsk University of Technology, Warsaw University of Technology, Poznań University of Technology, Wrocław University of Technology. The second group includes institutions with relatively low level of liquidity (a value lower by $50 \%$ of the average value for the whole group). In this group there are three academies of economics: University of Economics in Katowice, The Poznań University of Economics and Warsaw School of Economics; five universities: University of Gdańsk, Maria Curie-Skłodowska University in Lublin, University of Warmia and Mazury in Olsztyn, Nicolaus Copernicus University in Toruń and Adam Mickiewicz University in Poznań; one technical university: Silesian University of Technology in Gliwice, and one agricultural school: Warsaw University of Life Sciences. Providing a value lower than 1 for current liquidity ratio demonstrates that current assets of the institution are at a level lower than current liabilities. In case of an immediate need to pay off all current liabilities, the institution would have to take a long-term loan or sell long-term assets (those from which benefits accrue to the institution for a period longer than 12 months and which include, among others, real estate used in didactics and research). The details are presented in the picture below. 


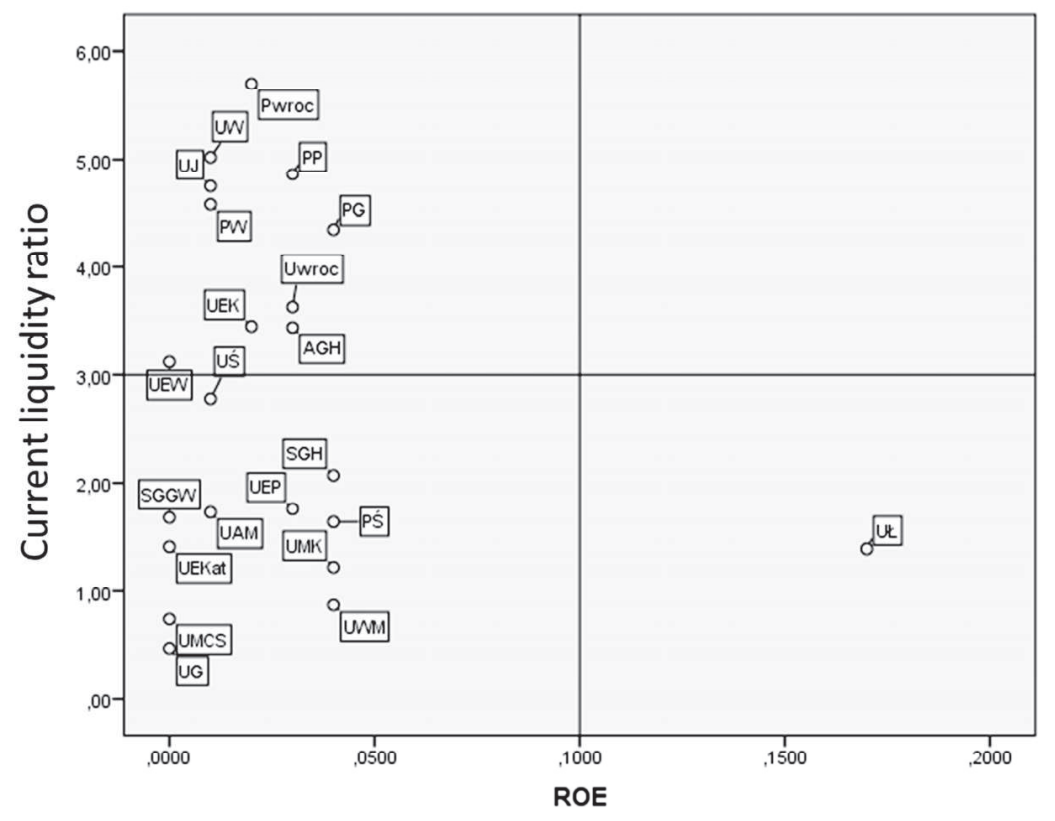

Source: Own elaboration.

The conducted analysis of correlation among variables used to assess organizational efficiency showed that relations exist between accounts receivable and accounts payable turnovers and ROE and ROA ratios. The correlation between accounts receivable turnover and accounts payable turnover can be explained by the distinct functionality of public higher education institutions. Due to the necessity of maintaining liquidity at higher public higher education institutions, a fundament ensuring the ability to carry out operations, an institution must ensure that resources obtained through accounts receivable are used to secure repayment of liabilities. The correlation, which was statistically significant ${ }^{28}$, between ROE and ROA ratios is also a result of distinct functionality of such institutions. Public higher education institutions must finance their operations mostly from equity. It stems from the balance sheet equation that if assets should be equal to sources of financing (equity and liabilities), then if equity is the main financing category, it should be close to the asset value. This explains the correlation between ROE and ROA.

\section{Conclusions and Recommendations}

Summarizing, the article can be divided into two parts. The first is an introduction, research assumptions and description of the research method along with a literature review. The second part is presentation of research results as well as summary and recommendations.

As a conclusion of article, it can be stated that when analyzing public higher education institutions from the perspective of their main processes, both efficiency and quality should be considered. It has been demonstrated that at most analyzed universities $(77 \%)$ in case of achieving the highest level of efficiency ${ }^{29}$ in the sample, a relatively low level of quality was achieved ${ }^{30}$. This shows that in case of most studied higher education institutions the posed research hypothesis cannot be rejected.

The problem of operations at higher education institutions is particularly important in the context of role of human capital and knowledge economy. Higher education institutions should meet the new social demands, particularly in the area of quality. 
The mentioned dilemmas create the necessity to implement constant monitoring in the area of economic nature of higher education institution operations as well as noticeable effects mainly in the area of rarely mentioned quality. For higher education institutions, it is important to achieve quality, yet it is only possible while maintaining an appropriate level of efficiency.

A key requirement of efficiency and quality analysis of public higher education institutions is having objective, comparable and pre-defined data pertaining to studied institutions. Efficiency as well as quality should be analyzed. It should be remembered that these concepts are not synonymous, although both are extremely important to make a correct assessment of the organization. Efficiency allows for assessment of an institution from the point of view of possessed (usable) inputs necessary to achieve specified effects. Quality is a measure in what way and to what extent, the institution meets the needs of stakeholders (mainly society). However, it should be considered that both measures are inseparable. An organization on the one hand, in order to function, should skillfully (economically) use available resources (this corresponds to efficiency). On the other hand, an organization functions in order to achieve its goals, which correspond to quality of organizational functioning (this is linked to quality). In order to achieve such goals, available resources are used, whose use is studied by measuring efficiency. This points to the fact that although efficiency and quality have different dimensions, they are inseparable aspects of functioning of every organization. From this stems that analysis of only one from two of the abovementioned aspects may give limited information about the institution. Moreover, the analysis should not be conducted for a higher education institution but rather for processes realized by organization. A minimum level should be main processes conducted by the higher education institution (didactics and research). In the article, direction of measurement was shown. Processes realized by higher education institutions with special attention to efficiency and quality should be the basis of this area of research. Variables used for analysis are exemplary variables. Each time, a list of used variables should be chosen from the perspective of adequacy to the current situ- ation in the higher education system as well as availability of data comparable to the analyzed sample of institutions. In addition, in the analysis, a type of institution should be considered (university, academy economic, technical university) and the level of economic development in which the institution functions (which mainly influences external quality measurement).

Higher education institutions should meet new social requirements, especially in the area of quality. For the management by the higher education institutions management and coping with the pressure of employers, it is crucial to pay attention to such factors as: adjusting the teaching content and anticipated educational effects to the needs of the economy, inconsistent demographic prospects, especially in the context of population growth and the age structure of the population economic in making decisions regarding the functioning of the unit. The above dilemmas create the necessity of introducing constant monitoring of efficiency and the rarely mentioned quality of the higher education institution.

The key requirement of the analysis of the efficiency and quality of public higher education institution is to have objective and comparable predefined data on the units under study. Both the efficiency (cost) as well as the quality of the higher education institutions should be examined. Evaluation of only one of the two above mentioned aspects may result in receive limited information about the higher education institutions. In addition, the analysis should not be conducted for higher education institutions but for processes carried out by them. The minimum level of research should be based at the main processes carried out by higher education institutions (didactics, research).

In view of the above, it seems advisable to develop at the national level ("over the higher education institutions"), e.g. at the level of the Ministry responsible for higher education, one methodology for conducting higher education efficiency and quality research. The Author of this work has formulated the following areas, which should be included in the developed efficiency and quality research methodology:

- indication of the processes carried out by universities;

- taken into account the expenditures, products and results of the function- 
ing of the higher education institution, which will appropriately enable the measurement of efficiency and quality;

- an indication of the IT tool (program) that should be used to conduct the research;

- proposals for the form of presentation of the results obtained.

The successive research on the efficiency and quality of higher education institutions can be modeled on the solution adopted in the monitoring of the graduates' fate. As part of the above, reports are generated and published centrally on the POLon portal. In the case of efficiency and quality measurement, consideration should be given to the development of a standard report, which will be periodically (e.g. on an annual basis, after the publication of financial statements by higher education institutions) made available on the website of the "Integrated Information System on Science and Higher Education".

\section{Endnotes}

1 The costs incurred as part of the business activity should not be higher than revenues generated by the conducted activity.

2 Together with the changes taking place in the socio-economic environment of the higher education system, one can speak of a new type of economy at higher education institutions. It is referred to as academic capitalism (Slaughter $\&$ Rhodes 2004). In addition, Suciu and Platis (2009) noticed that universities are struggling with new challenges and opportunities in the context of a dynamic socio-economic environment. Hence, the university should function as a company.

3 Art. 44 of the Act of 27 August 2009 on Public Finance (Journal of Laws, No. 157, item 1240, as amended).

4 It should be remembered that public universities were established to serve the society. To illustrate the above statement, we can quote the mission of the largest public university in Poland, University of Warsaw, which in its strategy has defined the mission as: "The University is not only for maintaining science and skills in the nation, to the extent that already stood in the world of scholars, but also improve them, propagate them and their theory for use by communities."

5 https://centrum.jakosci.pl/podstawy-jakosci,definicja-jakosci.html
6 Generally, institutions which belong to the public sector.

7 A legal act which in Poland places rights and responsibilities on public organizations in the area of managing possessed public resources.

8 Understood as not causing a negative financial result.

9 Efficiency Measurement System, version 1.3.0, source: http://www.hogler-scheel.de/ems/index. html, author: H. Scheel. Free access to software limited to research use by academia.

10 Diagrams were prepared using SPSS version 21.0 (Faculty of Economic Sciences, University of Warsaw). Curves on diagrams were created using a PowerPoint 2010 software (license owned by co-author).

11 Studied in context of a relations between inputs: personnel and non-personnel costs part of realizing didactic process and outputs: number of students being educated.

12 Costs of salaries and wages and other personnel costs.

13 Costs of didactic process less personnel costs (salaries and wages and others). Among these costs we can include costs of materials and energy used, depreciation of fixed costs and amortization of intangible assets, external services.

14 Ratio of inputs to outputs at the lowest level in the studied group.

15 Significant at the level of 0.01 (both sides).

16 From any type of employment.

17 Significant at the level 0,05 (both sides).

18 From any type of employment.

19 Significant at the level 0.01 (both sides).

20 In the studied group, universities educated the greatest number of students and where institutions which had non-commercial study paths, after which students can have a bigger problem with finding employment.

21 It is important to remember that this is only an assumption which confirmation would require additional study.

22 Studied in the context of relations between inputs: research costs and outputs: number of conducted research projects, publications and organized in 2015 scientific conferences.

23 Significant at the level of 0.01 (both sides).

24 Significant at the level of 0.05 (both sides).

25 Calculated as quotient of research costs and the number of patents.

26 Correlation significant at the level of 0.01 (both sides).

27 Correlation significant at the level of 0.05 (both sides).

28 At the level of 0.01 (both sides).

29 Equal to 1.

30 Measured quality ratio at a level lower than average for the studied sample. 


\section{References}

Act of 27 August 2009 on public finance (Journal of Laws, No. 157, item 1240, as amended).

Bradley, S., Johnes, J., \& Little, A. (2010). The measurement and determinants of efficiency and productivity in the FE sector in England. Bulletin of Economic Research, 62(1), 1-30. DOI:10.1111/ j.1467-8586.2009.00309.x.

Brzezicki, Ł. (2017). Efektywność działalności dydaktycznej polskiego szkolnictwa wyższego. Wiadomości Statystyczne, 11(678), 56-73.

Brzezicki, Ł., \& Pietrzak, P. (2018). Produktywność dydaktyczna publicznych uniwersytetów w latach 2010-2015. Edukacja, 1(144), 96-105. DOI: $10.24131 / 3724.18010$

Camanho, A. S., \& Dyson, R. G. (2005). Cost efficiency, production and value-added models in the analysis of bank branch performance. Journal of the Operational Research Society, 56(5). DOI: 10.1057/ palgrave.jors.2601839

Capaldi, E. D., \& Abbey, C. W. (2011). Performance and costs in higher education: A proposal for better data. Change: The Magazine of Higher Learning, 43(2), 8-15. DOI: 10.1080/00091383.2011.550250

Charnes, A., Cooper, W. W., \& Rhodes, E. (1998). Measuring the efficiency of decision making units. European Journal of Operational Research, 2(6), 429-444. DOI: 10.1016/0377-2217(78)90138-8.

Czapiewski, K., \& Janc, K. (2013). Edukacja jako czynnik rozwoju Mazowsza. Trendy Rozwojowe Mazowsza, (11).

Dwórznik, M. (2018). Efektywność i jakość czołowych publicznych uczelni funkcjonujących na terenie województwa mazowieckiego na tle największych uczelni działających w Polsce. Mazowsze Studia Regionalne, (27), 29-42. DOI: 10.21858/ msr.27.02.

Falcon, D. (1973). Cost models for university planning. Higher Education, 2(2). DOI: 10.1007/ BF00137764.

Franco, A. (1991). Financing higher education in Colombia. Higher Education, 2(2), 163-176. DOI: 10.1007/BF00137071.

GUS (Statistics Poland). (2016). Szkoly wyższe i ich finanse 2015. Warszawa: Statistics Poland.

Janc, K., \& Czapierwski, K. (2021). Szkolnictwo wyższe / Higher education. In P. Śleszyński \& K. Czapiewski (Eds.), Atlas Wyszehradzki/ Visegrad Atlas (pp.168-173). Instytut Współpracy Polsko-Węgierskiej im. Wacława Felczaka; Polskie Towarzystwo GeograficzneWacława Felczaka; Polskie Towarzystwo Geograficzne.

Kaneko, M. (1997). Efficiency and equity in Japanese higher education. Higher Education, 34(2), 165-181. DOI: 10.1023/A:1003005519014.
Leitner, K., Prikoszovits, J., Schaffhauser-Linzatti, M., Stowasser, R., \& Wagner K. (2007). The impact of size and specialisation on universities' department performance: A DEA analysis applied to Austrian universities. Higher Education, 53(4), 517-538. DOI: 10.1007/s10734-006-0002-9.

Maślankowski, J., \& Brzezicki, Ł. (2020). Wykorzystanie mediów społecznościowych w szkolnictwie wyższym. Wiadomości Statystyczne, 65(2), 30-42. DOI: 10.5604/01.3001.0014.0455.

McMillan, M., \& Datta, D. (1998). The relative efficiencies of Canadian universities: A DEA perspective. Canadian Public Policy - Analyse de Politiques, 24(4), 485-511. DOI: 10.2307/3552021.

Modzelewski, P. (2009). System zarzadzania jakościa a skuteczność i efektywność administracji samorzadowej. Warszawa: Wydawnictwo Fachowe CeDeWu.

Nazarko, J., Chodakowska, E., \& Jarocka, M. (2012). Segmentacja szkół wyższych metodą analizy skupień versus konkurencja technologiczna ustalona metodą DEA - studium komparatywne. Prace Naukowe Uniwersytetu Ekonomicznego we Wroctawiu, (242), 163-172.

Pietrzak, P., \& Baran, J. (2018). Efektywności i skuteczność kształcenia w publicznym szkolnictwie wyższym w Polsc. Nauka i Szkolnictwo Wyższe, 2(52). DOI: 10.14746/nisw.2018.2.3.

Pietrzak, P., \& Gołaś, M. (2018). Efektywność i skuteczność kształcenia akademickiego na przykładzie Szkoły Głównej Gospodarstwa Wiejskiego w Warszawie. Zeszyty Naukowe SGGW - Ekonomika i Organizacja Gospodarki Żywnościowej, (122), 17-28. DOI: 10.22630/EIOGZ.2018.122.11.

Ramírez-Correa, P., Peña-Vinces, J. C., \& AlfaroPérez, J. (2012). Evaluating the efficiency of the higher education system in emerging economies: Empirical evidences from Chilean universities. African Journal of Business Management, 6(4). DOI: 10.5897/AJBM11.1982.

Slaughter, S., \& Rhoades, G. (2004). Academic capitalism in the new economy. Baltimore, Md.: The Johns Hopkins University Press.

Staniszewska, M., \& Stasik, M. (2012). Jak poprawić funkcjonowanie kontroli zarzadczej $w$ administracji publicznej - rola audytu wewnętrznego i Najwyższej Izby Kontroli. Paper presented at the seminar meeting of the College of the Polish Supreme Audit Office entitled „System kontroli zarządczej w Polsce - sukcesy i porażki”. Warszawa.

Suciu, C. M., \& Platis, M. (2009). Entrepreneurial university in the new economy. Annals of Faculty of Economics.

Taylor, B., \& Harris, G. (2004). Relative efficiency among South African universities: A data envelopment analysis. Higher Education, 47(1). DOI: 10.1023/B:HIGH.0000009805.98400.4d. 
Taylor, E. S., \& Tyler, J. H. (2012). The effect of evaluation on teacher performance. The American Economic Review, 102(7), 3628-3651. DOI: 10.1257/aer.102.7.3628.

Taylor, J. (2001). Efficiency by performance indicators? Evidence from Australian higher education. Tertiary Education and Management, 7(1). DOI: 10.1023/A:1011349020908.

Teichler, U. (2013). Universities between the expectations to generate professionally competences and academic freedom experiences from Europe. Procedia - Social and Behavioral Sciences, 77, 421-428.
DOI: 10.1016/j.sbspro.2013.03.097Elsevier Ltd, 2013.

Thanassoulis, E. (2003). Introduction to the theory and application of data envelopment analysis. A foundation text with integrated software. Norwell: Kluwer Academic Publishers.

Thanassoulis, E., Kortelainen, M., Johnes, G., \& Johnes, J. (2011). Costs and efficiency of higher education institutions in England: A DEA analysis. Journal of the Operational Research Society, 62(7). DOI: $10.1057 /$ jors.2010.68. 